\title{
Shakespeare: from author to audience to print, 1608-1616
}

Book or Report Section

Accepted Version

Ioppolo, G. (2014) Shakespeare: from author to audience to print, 1608-1616. In: Late Shakespeare, 1608-1613.

Cambridge University Press, Cambridge, UK, pp. 139-157. ISBN 9781107463196 Available at http://centaur.reading.ac.uk/40816/

It is advisable to refer to the publisher's version if you intend to cite from the work. See Guidance on citing.

Publisher: Cambridge University Press

All outputs in CentAUR are protected by Intellectual Property Rights law, including copyright law. Copyright and IPR is retained by the creators or other copyright holders. Terms and conditions for use of this material are defined in the End User Agreement. 


\section{CentAUR}

Central Archive at the University of Reading

Reading's research outputs online 


\section{CHAPTER 8}

\section{Shakespeare: From Author to Audience to Print, 1608-1613}

By 1608 Shakespeare was an experienced actor, an accomplished and prestigious dramatist and a man who had gotten quite rich from the business of theatre. By late 1608 , he was the only dramatist who had become a sharer both in his playing company and two of its income-earning playhouses. In fact, Shakespeare became a financial investor in these three consortia as soon as each was set up. The first consortium was the Chamberlain's Men, later the King's Men, in which he purchased a share at its inception in 1594 . The second was the Globe theatre, rebuilt from the Theatre in Shoreditch, which was originally financed by James Burbage and his family in 1576. Although Shakespeare does not appear to have been an investor in the original Shoreditch structure prior to 1599 , he was shrewd enough to purchase a share when Burbage's sons Cuthbert and Richard fell out with their freeholder and decided to dismantle it and rebuild it in 1599 as the Globe. When Richard Burbage took up his father's lease on Blackfriars abbey in 1608, Shakespeare also purchased a share in it. So by the end of 1608 when the King's Men leased Blackfriars, Shakespeare earned income in every possible way from the success of his plays: he sold his plays to and derived income in theory or in practice from consortia that included himself. This meant that he did not relinquish the artistic control or financial interest that non-sharer dramatists did in selling plays to a company or even to a printer. ${ }^{i}$ Not only was he experienced in the transmission of his play-texts from author to censor to actor to theatrical audiences, and later printers and literary audiences, but he also earned income at nearly every stage of this transmission, providing him with powerful incentives to transmit his texts exactly as he wished. 


\section{Early Shakespeare}

In 1608 Shakespeare was a successful artist who had begun his career as a junior collaborator with experienced dramatists and was five years away from ending it as a senior collaborator with less experienced dramatists. Ben Jonson may have been pretentious in claiming that he completed Volpone in a mere five weeks 'in his owne hand without a Co-adiutor / Nouice, Iorney-man or Tutor'. ${ }^{\text {ii }}$ But his categories for collaborators may have been commonly used, if only by Jonson when he collaborated throughout his career with such dramatists as Thomas Nashe, John Marston, George Chapman, Anthony Munday, Henry Porter, Thomas Dekker, and Henry Chettle, among others. Using contemporary definitions adapted from the $O E D$, as well as Jonson's comments about authorship throughout Poetaster, he would have considered the main poet or author to be far above co-adjutors (assistants), novices (inexperienced writers) and journeymen (those newly qualified after having finished apprenticeships). To Jonson, each of these collaborators served in subservient positions to more experienced master poets. He probably mentioned the 'Tutor' satirically here to mock those dramatists, including Heywood, who revised other authors' manuscripts, because Jonson complained especially when 'second' pens, as in Sejanus, later altered or emended his work without his approval. ${ }^{\mathrm{iii}}$ Or perhaps Jonson mocks those collaborators who did not limit their role to writing their share or part of a play but insisted on joining and correcting the shares of collaborators.

As Henslowe's 'Diary' and hundreds of pages of his and Edward Alleyn's papers demonstrate, dramatists could approach acting companies or their agents with suggestions of plays they wanted to write or authors could be approached by companies and agents and commissioned. ${ }^{\text {iv }}$ Unless on some form of exclusive 
contract, dramatists could write for any company of their choice at any given time, but in practice, they seemed to remain loyal to the same companies, especially as dramatists could exert some form of leverage with friends or former associates in negotiating pay and working conditions. Henslowe paid a series of advances to each of his contracted writers as they turned in acts or scenes, making the final payment at the submission of the last portion of the play. In the 1590s, the standard total payment for a play was $£ 5$ to $£ 7$, rising to $£ 20$ by 1613 . $^{\mathrm{V}}$ Henslowe apparently expected authors to submit to him fair, and not foul, copies of plays, which could immediately be used by theatrical personnel and submitted to the censor, the Master of the Revels. Jonson's boast of finishing Volpone in five weeks does not mark him as speedy, given that completion times for plays in Henslowe's Diary range from about two weeks to several months. Of course, some plays commissioned by Henslowe were never completed, and some were reassigned to other authors, even in the midst of composition.

As recorded in Henslowe's 'Diary' and noted on early Quarto title pages, at least three of Shakespeare's plays, Titus Andronicus and Henry VI Parts II and/or Part III, were written for one or more companies, including Pembroke and Sussex's Men, to which he belonged before his move in 1594 to the newly re-formed Chamberlain's Men. Shakespeare's name does not occur in the 'Diary' probably because Henslowe's notations of having commissioned dramatists does not begin until 1597, three years after Shakespeare began to be a sharer in and to work exclusively for the Chamberlain's Men. So there is every possibility that prior to 1594 Shakespeare had occasional if not routine dealings with companies and personnel that were later documented in Henslowe's 'Diary'. 
In fact, evidence throughout the 'Diary' supports three important points about the transmission of play-texts that are often overlooked by modern scholars. The first is that dramatists did not always complete a play for a company before beginning the next but had one or more plays in composition at any given time with that same company. This meant that writers had nearly continual access to players throughout the composition of plays, rather than occasional access only at the time of being commissioned to write a play and then at the time of the play's submission. Henslowe's 'Diary' especially documents not his occasional but weekly and sometimes daily interaction with commissioned dramatists; that Shakespeare was a sharer in his company, as Henslowe's dramatists were not, guarantees his near-daily access to his company during performance periods. The second point is that acting companies did not 'compete' or see themselves as 'rivals' with each other, particularly as many personnel, including dramatists, were in ever-shifting roles with a variety of companies over the years. Everyone knew everyone else, and most personnel had worked together earlier and/or would work together in the future.

This leads to the most important point: while there may have been a hierarchy among dramatists, with Shakespeare ranked at the bottom early in his career as a 'novice', 'co-adjutor' or 'journeyman' and at the top as a master poet at the end of his career, the transmission of a play-text was a collaborative effort. Dramatists worked with company personnel, including players, bookkeepers, scribes, managers and their agents, especially in preparing their plays for submission to the censor and for implementing any changes he had required. Dramatists also read newly completed plays to the companies for which they were written and responded to the players' suggestions. Whenever possible the original dramatists revised plays at any given point: during composition; after return from the censor; during rehearsal; after any 
period of performance, particularly for later revivals and for performance at later venues; and possibly before publication. For dramatists, who were without doubt proprietary about their own artistic creations, plays had a continual and fluid life which involved them for as long as possible, and these texts took not a linear path from author to actor to audience to print but a circular one in which the play could and did return to the author. This is certainly the way Shakespeare saw his role as dramatist. $^{\text {vi }}$

Prior to 1608 , Shakespeare, like his collaborators and colleagues, used the genres and topics currently in vogue. From the early 1590s these were formulaic revenge tragedies, as in Titus Andronicus, light comedies such as The Two Gentlemen of Verona, and patriotic history plays, including those later published as Parts 2 and 3 of Henry VI. By the early 1600s, the fledgling theatrical profession of the 1590s had grown into a well-established and externally- and internally-regulated profession. As a result, dramatists and players, and the playhouses they used and the audiences that filled them, had become more sophisticated in their tastes and demands. While it may seem easy to credit Shakespeare alone with professionalising early modern drama and theatre, contemporaries such as Marlowe and Jonson and entrepreneurs such as Henslowe, Alleyn and the Burbages had also contributed to this expansion and refinement of the profession. So when Shakespeare moved on in the first years of the 1600s to much more complex and demanding plays, including such dark comedies as All's Well that Ends Well and Measure for Measure and powerful tragedies such as Hamlet and Macbeth, he did so not only to suit his own artistic designs but those of his more sophisticated audiences. By 1608 he appeared ready to experiment more drastically with the three genres of comedy, history and tragedy in which he had already worked. Ironically, his late plays, with their mixture of fantastical romance, 
history and tragedy, and, often, some form of masque, were still categorised into one of these three standard genres when his collected works were published in the First Folio in 1623, regardless of the ways in which they reshaped concepts of genre.

The year 1608 also marks the date of the King's Men's decision to move into the private Blackfriars theatre, which not only offered a more sophisticated type of venue than the Globe, still used for summer performances, but attracted an intellectual and more discerning audience. While the Globe, with its hierarchy of admission prices, continued to cater to a wide range of theatregoers from working-class to middle-class to aristocrat, Blackfriars brought in students from the Inns of Court who could afford the higher admission prices and would expect more spectacular stage effects, sets and costumes and dimmable lighting. Shakespeare began to exploit the new wave of theatrical and dramatic opportunities now available to him, for example in the masques in The Winter's Tale and The Tempest and the storm and magical banquet brought by flying harpies in the latter play. Yet his company's move finally into Blackfriars by 1609 did not invent these opportunities but instead adapted them from another form of private entertainment: the court masque. ${ }^{1}$ King James's wife Anne and his son Henry, at least, seemed especially enamoured of patronising or performing in masques. However, while most of Shakespeare's most prominent contemporaries and colleagues such as Munday, Jonson, Middleton, and Heywood wrote court masques, there is no evidence that he did, even though his company was directly patronised by the King. Perhaps Shakespeare worked these masques into his plays instead to guarantee maximum profit for his company in attracting public and private theatre audiences, or simply because he felt uncomfortable with a genre that on its own had no theatrical or dramatic depth, or for a variety of other reasons. But at

\footnotetext{
${ }^{1}$ On Shakespeare's use of the features of the masque, see David Lindley, Blackfriars, music and masque: theatrical contexts of the last plays in The Cambridge Companion to Shakespeare's Plays, ed. Catherine S. Alexander (Cambridge University Press, 2009), 29-45.
} 
least Shakespeare responded to the concerns of his audience in terms of the latest form of entertainment through the use of the company's latest venue, the Blackfriars, which came closest to the type of royal court venue that most law students would ever come.

Shakespeare modestly began his career by adapting simplistic genres already being used by other dramatists, possibly because he lacked confidence about the extent of his role in the transmission of his texts from author to audience. But he ended his career by challenging himself to invent or reinvent more extraordinary genres, demonstrating by that time that he trusted his company and himself to circulate his texts in the most shrewd and adept ways possible. While Ben Jonson increasingly felt the need to control every aspect of the transmission of his texts to theatre and literary audiences, even forcing playgoers to agree to a contract at the beginning of Bartholomew Fair and watching as compositors set and print the forms of his Quarto and Folio texts, Shakespeare loosened his control over audiences. He was experienced and perhaps wise enough to know that there could be no transmission of a text in any form without the audience, and the only way to control the audience was to allow them to think that they controlled him.

We need to recognise this inverted authorial control practiced by Shakespeare especially in reconsidering the publication of his texts in Quarto form in the early and middle part of his career. Beginning in the eighteenth century, scholars and editors such as Alexander Pope, Edmond Malone, F. G. Fleay, E. K. Chambers, A. W. Pollard, W. W. Greg, Stanley Wells and John Jowett, to name only a very few, have debated, seemingly endlessly, to what degree each of these Quartos show Shakespeare's participation in the printing process. Yet we need to accept that when Shakespeare's company decided to sell plays to printers, Shakespeare as a sharer was 
part of this decision, and he derived a share of the income from such sales, even though he had first sold the texts to his own company. Texts of his plays may occasionally have been sold in abridged or adapted forms without his and the company's permission, as was clearly the case with the 1597 first Quarto of Romeo and Juliet and the 1603 first Quarto of Hamlet, as noted on the title page of the second Quarto of each text. Because so many other Quartos were clearly printed from Shakespeare's own foul papers or from theatrical manuscripts used by his company, he at least contributed to the publication of these plays even if he did not actually participate in it. That he did not control this publication, as Jonson did, does not mean that he did not care about it. He handed over his foul papers or acting texts to printers with whom he seemed to have had a continual if not cordial relationship. These printers, who were licensed professionals, could most likely be trusted not only to return these papers to him if necessary but to produce printed texts of a standard employed by the profession.

In fact, by 1608 the following plays had been printed, by at least the date listed, from a text supplied by Shakespeare or his company:

1594: Titus Andronicus

1597: Richard III; Richard II

1598: Henry IV, Part I; Love's Labour's Lost

1599: Romeo and Juliet

1600: Henry IV, Part II; Henry V; A Midsummer Night's Dream; Merchant of Venice

1602: The Merry Wives of Windsor

1604: Hamlet 
Some of these plays were also subsequently reprinted. Still circulating in print but most likely not printed from a text associated with the Chamberlain's Men was a shortened form of Henry VI, Part II as The First part of the Contention of the Two Famous Houses of York and Lancaster (1594) and of Henry VI, Part III as Richard Duke of York (1595) and, as mentioned earlier, of Romeo and Juliet (1597) and Hamlet (1603). Two other plays had been entered in the Stationers' Register in advance of publication but probably did not appear in print: As You Like It in 1600 and Antony and Cleopatra in 1608. Troilus and Cressida had been entered in 1603 but was first printed in 1609 . The plays written before 1608 that did not appear in print before the publication of the 1623 First Folio were The Two Gentlemen of Verona, The Taming of the Shrew, The Comedy of Errors, King John, Much Ado about Nothing, Julius Caesar, Twelfth Night, Measure for Measure, All's Well that Ends Well, Macbeth, Antony and Cleopatra, and Timon of Athens. While Othello was printed in the Folio, it appeared first in Quarto in 1622. In 1593 and 1594 Venus and Adonis and The Rape of Lucrece were published by Richard Field, one of Shakespeare's neighbours from Stratford-on-Avon, with dedications by the author to Henry Wriothesley, $3^{\text {rd }}$ Earl of Southampton, illustrating Shakespeare's earliest command of the medium of print. The Sonnets, although written much earlier, were published in a collected edition in $1609 .{ }^{\text {vii }}$

\section{Late Shakespeare}

From 1608, Shakespeare wrote or co-wrote seven plays: Pericles, Coriolanus, Cymbeline, The Winter's Tale, The Tempest, Henry VIII and The Two Noble Kinsmen. 
While nearly half of his plays written before 1608 were printed in Quarto texts, of the later plays, only Pericles appeared in print before Shakespeare's death in 1616. But this text was published in a 1609 Quarto so corrupt that probably neither Shakespeare nor his company contributed to its publication. Notably The Two Noble Kinsmen, printed first in Quarto in 1634, was a collaboration between Shakespeare and John Fletcher. Neither The Two Noble Kinsmen nor Pericles was included in the 1623 Folio, because the compilers John Heminges and Henry Condell did not consider the two plays to be part of the genuine Shakespeare canon or they could not arrange for the rights to publish them or for some other reasons. However, Heminges and Condell did include Shakespeare and Fletcher's collaborative play Henry VIII which they presumably thought could round out the collection of other history plays printed in the Folio. That Shakespeare and his company succeeded in keeping six of his seven late plays out of print, even though they had been willing to publish half of his earlier plays, suggests first that the King's Men wanted to ensure that the texts of the late play could not be used for performance by other companies. Second, it is probable that the King's Men were planning some type of collected edition of Shakespeare's plays at least by the early 1610s. Thus the later plays were to be kept out of print until that time.

With the exception of the Quarto text of Pericles, Shakespeare's late plays follow a similar path of transmission. Those printed from foul papers show false starts and inconsistencies in plot, characters and structure typical of Shakespeare and other dramatists in the heat of composition. Those set from fair copies, sometimes authorial and sometimes scribal, show an author finely attuned to performance opportunities and concerns, as well as anticipating potential problems. Theatrical 'books' (the contemporary term for promptbooks) show the circularity of the text moving to and 
from the author. At every stage, the type of text that lies behind those eventually printed in the First Folio demonstrates a close and familiar collaboration between Shakespeare the dramatist and the theatre personnel, including his co-investors, to whom he entrusted his texts.

While most scholars assume from his documented residences in Stratford from about 1612 that he wrote his last plays in retirement and at leisure, it is difficult to believe that as a sharer in the three consortia he did not participate actively in the artistic and financial concerns of his company and its theatres until the end of his life. In his last two plays, The Two Noble Kinsmen and Henry VIII, he collaborated with Fletcher. As collaborators routinely appeared to have portioned out whole acts, and occasionally whole scenes only, Shakespeare did not need to sit in the same room as Fletcher to co-write these or any other plays. In fact, there seems to be a noticeable and not seamless integration of those acts and scenes written by Fletcher in Shakespeare's two last plays, suggesting that Shakespeare did not, as Heywood did, adjust his late play texts after all the collaborators' work was submitted in order to hide drastic shifts in style among them. It may be that Shakespeare was training Fletcher, who had been writing for some years previously with Francis Beaumont, to take over the role of chief dramatist of the King's Men. Thus Shakespeare may have allowed or expected Fletcher to finalise a collaborative text, as perhaps Shakespeare did as a junior collaborator in the 1590s. However, Fletcher, who may have joined his portions of plays into Beaumont's portions after their completion, was probably assigned the role by the company as the final overseer of a co-written play-text. But rather than seeing Shakespeare as hesitant to come out of retirement, and thus lacking interest in the final versions of his late plays, we need to see him as slowly but surely increasing the roles of his chief collaborator in the transmission of these texts. As the 
textual histories of these plays outlined below imply, Shakespeare was not the master poet, apprentice, co-adjutor, journeyman or even tutor in his last years. Instead he ended his writing career the way he began it: as the modest collaborator.

\section{Pericles, Prince of Tyre}

Edward Blount's 1608 entry of his intention in the Stationer's Register to print the 'book', or promptbook, of Pericles was not apparently followed by a printed Quarto, and the play was printed and then reprinted by Henry Gosson in the following year. The play's omission from the 1623 First Folio may be due to one or more factors. First, the printers may not have been able to obtain the rights to print it, either from Gosson, or from Thomas Pavier who had reprinted it in 1619 with a false date of 1609. Second, the text in the first Quarto is so corrupt that the Folio compilers and printers may have been unable to deal with its problems, including the high incidence of verse being printed incorrectly as prose and numerous other confusions or inconsistencies, most likely because this text was not printed from a manuscript supplied by Shakespeare or his company. ${ }^{\text {viii }}$ Scholars long ago agreed that the manuscript instead was surreptitiously acquired by Gosson and/or was 'reported' or reconstructed in part or whole by memory, thus making the Quarto 'bad', to use a term invented by Pollard. ${ }^{\text {ix }}$ Markers of such a provenance include 'several instances of confusion of the action within a scene that suggest awkward attempts to glue together fragments of an imperfectly remembered original', according to Philip Edwards. He argues for two reporters of the manuscript, each using different techniques, with the second hand taking over in the second half of the play, implying that there was only one author rather than two or more. ${ }^{\mathrm{x}}$ But the text may have been mixed in other ways, possibly in including both authorial foul and fair copy. ${ }^{\mathrm{xi}}$ 
Published in the same year as the Quarto of Pericles, and telling the same story is George Wilkins' prose history, The Painfull Adventures of Pericles Prince of Tyre, the title page of which names it 'the true History of the Play of Pericles, as it was lately presented by the worthy and ancient Poet John Gower'. That Wilkins attempted to reclaim the story does not prove, as Gary Taylor argues, that he was Shakespeare's chief or only collaborator in the play. However, Shakespeare most likely did have one or more collaborators, possibly including John Day who wrote Acts 1 and 2 while Shakespeare completed the last three acts. ${ }^{\text {xii }}$ The Quarto lacks act divisions possibly because its printers' copy was assembled from a source other than the two or more authors' sets of papers, especially as these authors had been apportioned whole acts to write and would have noted the divisions. The poorlyexecuted printing of the play introduced further complexities into the text in terms of lineation and casting-off, resulting in a text that seems far removed from authors, actors and audience, preventing us from judging accurately Shakespeare's exact share of the play or its transmission.

\section{Coriolanus}

Coriolanus was apparently intended to be the first play printed under the list of 'Tragedies' in the First Folio but was displaced by Troilus and Cressida, the printing of which had probably been held up due to problems with ownership. Thus when the First Folio began to go into print in 1622, Coriolanus may have been considered as the most prestigious of all the tragedies, possibly because of its classical story, rather than simply the last, and newest, of Shakespeare's tragedies. The Folio text shows some corruption but was probably printed from Shakespeare's foul papers, possibly mixed with some fair copy, judging from its false starts, idiosyncratic spellings and 
the inconsistencies in stage directions and particularly in names used in speechprefixes and in the dialogue. All of these confusions signal a composing author. ${ }^{\text {xii }}$ While the confusions in character names may have been due to similar confusions in Shakespeare's source, Sir Thomas North's translation of Plutarch's Lives of the Noble Grecians and Romans, Shakespeare's other foul paper texts show similar confusions, especially in alternating between generic and character names. His characteristic spelling, particularly in words beginning with 'si' written as 'sci', such as 'Sicinius' written as 'Scicinius', cannot be doubted. However, R. B. Parker's contention that Shakespeare had a 'habit of using upper-case Cs improperly in mid-sentence' ${ }^{\text {xiv }}$ does not take into account that in secretary handwriting, minuscule 'c' (and not 'lower case', a term reserved for print and not handwriting) is usually indecipherable in primary position in a word. In using majuscule ' $\mathrm{C}$ ' in the primary position in a word, Shakespeare wrote like everyone else.

Philip Brockbank argues that the text shows a lack of scribal correction and Shakespeare's 'readiness to act almost as his own bookkeeper'. ${ }^{\mathrm{xv}}$ That is, Shakespeare anticipates on occasion the points at which the mind of the composing author will not be clear to the bookkeeper who has to prepare the text for performance. Such practice by Shakespeare may not have been typical only of his later career, for his three-page addition to the collaborative manuscript 'Book' or prompt-book of Sir Thomas More shows him working with that play's bookkeeper in making minor revisions to his fair copy. ${ }^{\text {xvi }}$ As is typical of composing authors who do not usually stop in the heat of writing to attend to scene notation, the text of Coriolanus is divided into acts but has a scene notation only in Act 1 , Scene 1 . However, the unusually descriptive stage directions show a mature Shakespeare who is no longer terse or basic but establishing a precise stage setting and costumes, as in 'Enter Volumnia and Virgilia, mother and 
wife to Martius: They set them downe on two lowe stooles and sowe', 'They all shout and waue their swords, take him vp in their Armes, and cast vp their Caps', and 'Enter the Patricians, and the Tribunes of the People, Lictors before them:

Coriolanus, Menenius, Cominius the Consull Scinius and Brutus take their places by themselues: Coriolanus stands' ${ }^{\text {xii }}$ These types of stage directions show not an author exerting control from semi-retirement in Stratford but a dramatist directing the actors. ${ }^{\text {xviii }}$ That there was no assigned role of director before the Restoration does not mean that this role was not taken up by senior actors or sharers; without doubt Shakespeare would have assisted if not supervised the direction of his own plays. Parker sensibly argues that the text of the play underwent some regularisation, including in act divisions, when the King's Men moved into Blackfriars in 1608-9, especially as that theatre offered music between the acts. ${ }^{\text {xix }}$

The compositors of the Folio text of the play closely followed their manuscript copy and on occasion, produced errors in the lineation of at least 300 verse lines, probably due to Shakespeare revising in the margin while composing, without clearly marking the beginning and end of new lines. ${ }^{\mathrm{xx}}$ This type of marginal revision can be seen in a number of his earlier plays, most notably A Midsummer Night's Dream, and thus is typical of his entire career. The heavy punctuation in the text, which is uncharacteristic of Shakespeare and most of his colleagues and collaborators, may be due not to the compositor but to the editors of the texts used to print the Folio. The professional scribe Ralph Crane especially insisted on heavy punctuation in his fair copy manuscripts, used as printers' copy for a number of the plays that appear at the beginning of the Folio (see below). As Coriolanus was to be printed in the first position under 'Tragedies' its authorial manuscript may too have received heavy correction of punctuation in order to make it compatible with the transcripts made by 
Crane. Parker's assessment that this Folio text 'is remarkable for its deliberately unmusical, compressed, cacophonous, and jagged style ${ }^{\text {xxi }}$ does not reveal a lazy or lax author who failed to correct or revise his original draft. Instead we see here an experienced dramatist who is fully confident that this text in particular will be refined in his collaboration with the players and that his texts in general remain fluid from author to actor. That is, Shakespeare knows the text is not fixed and immutable at this point but has only begun its transmission from author to players and thus to audience.

\section{Cymbeline}

This play may have been printed in the 1623 First Folio from one of the several manuscripts prepared by the professional scribe Ralph Crane. Extant manuscripts in his hand include copies of Fletcher's Demetrius and Enanthe, Fletcher and Massinger's Sir John Barnavelt, Middleton's The Witch, and three of the variant six

manuscripts of Middleton's A Game at Chess. ${ }^{\text {xii }}$ Crane, who signed his name 'Raph' (thus pronouncing it 'Rafe') in Demetrius and Enanthe and specialised in copying dramatic or literary texts, apparently did not work as a company bookkeeper but was associated with the King's Men at various times. Whenever possible in copying dramatic manuscripts, he seemed to have worked under the direction of, or in collaboration with, the texts' original authors, including Middleton, Fletcher and Massinger. Crane made a transcript of Sir John van Olden Barnavelt for the King's Men in the typical Folio size of theatrical manuscripts. But his other extant manuscripts are Quarto-sized and are presentation, commissioned or, possibly, printer's copies; that is, these manuscripts are reading and not acting texts. If the King's Men began to withhold the publication of Shakespeare's plays after 1608 because they were planning to produce a collected edition, Crane may have been 
commissioned to begin making printers' copies of the plays at least from the early to mid 1610s, possibly under the direction of Shakespeare. That Crane added an elaborate and personal dedication of his own to Sir Kenelm Digby, to whom he gave Demetrius and Enanthe on 27 November 1625, does not mean that he appropriated authors' texts without their permission: Fletcher had died suddenly of the plague a few months before this date, so Crane may have felt it necessary to supply the dedication that the author could not.

All of Crane's fair copy manuscripts show an extremely neat, consistent and professional copyist who is clearly thinking about overall layout before he begins writing. For example, in Demetrius and Enanthe and in The Witch, he anticipates the text by copying the entrance directions a line or two before they appear. In fact, he can be seen as a 'fussy' or precise scribe. ${ }^{\text {xiii }}$ His usual patterns of copying are apparent in the manuscript used to print the first edition of Measure for Measure in the Folio: he has consistently introduced or regularised apostrophes, colons and parentheses and other punctuation, as well as act-scene divisions and speech-prefixes. He has also used 'massed' stage entries; that is, he lists all characters in the scene in the opening stage direction rather than at their points of entrance. Crane has also hyphenated compound words and deleted oaths, if the company had not done so by $1606,{ }^{\text {xxiv }}$ and occasionally wrote out dramatis personae lists at the end of the plays he copied for the Folio.

While Crane corrected or regularised grammar, introducing 'incidental' or minor variants, he did not alter the dramatic features of the text, such as plot, setting, structure, character, or dialogue. Thus he does not introduce 'substantive' or major variants. In effect, he left intact plays' obvious inconsistencies and duplications in dialogue and plot, for it was clearly not his role to improve or revise texts, only to 
regularise them. That is, Crane did not control a text; he copied it. In listing the unnamed Duke's first name as 'Vincentio' in the list of dramatis personae at the end of Measure for Measure, he probably took direction from the players. While scholars have agreed that Crane made printers' copies of the Folio's first four plays, The Tempest, The Two Gentlemen of Verona, The Merry Wives of Windsor, and Measure for Measure, he most likely also produced the copies for Cymbeline and The Winter's Tale. ${ }^{\mathrm{xxv}}$ In fact, Crane may have been contracted to make fresh transcripts of all the texts to be printed in the First Folio, and either he or his employers, or both, ended the agreement for some reason after only some texts had been copied. ${ }^{\mathrm{xxvi}}$ This recopying may have occurred over several years from the 1610 s, rather than immediately prior to 1622 when the printing of the Folio began.

Taylor and Jowett followed E. A. J. Honigmann in arguing that the manuscript used by Crane to transcribe Cymbeline showed a change of writers, evidenced by an abrupt change of spelling, between Act 2 Scene 4 and the following scene. ${ }^{\text {xxvii }}$ However, such abrupt changes may occur in manuscripts made by single writers or scribes, so the possibility remains that Crane was copying from an authorial or scribal fair copy used in the theatre. The Folio text otherwise does not suggest any major problems, errors or revisions. ${ }^{\text {xxviii }}$ E. K. Chambers, who routinely dismissed arguments for authorial revision in Shakespeare's plays, followed previous critics in arguing that the vision in 5.4 is a 'spectacular theatrical interpolation', and thus that the manuscript behind Crane's must have been a later transcript rather than foul papers. ${ }^{\text {xxix }}$ J. M. Nosworthy disputed this view, arguing instead that the Folio was printed from a scribal transcript of 'difficult foul papers' and that the text contains no non-authorial additions or interpolations. ${ }^{\mathrm{xxx}}$ A scribal transcript would produce the full notations of act and scene divisions if Crane did not make such notations 
himself. As much as we would like to see a set of foul papers behind Crane's transcript of Cymbeline, the lack of Shakespearean characteristics, such as false starts, inconsistencies and unusual spellings, makes it difficult to support this argument. The play was printed in the First Folio at the end of the Tragedies, rather than with the 'Comedies', most likely because it was a late acquisition by the printers. Once again, the text of the Folio suggests a dramatist confident that his text will be further developed in rehearsal and performance with his own participation.

\section{The Winter's Tale}

The Master of the Revels, Sir Henry Herbert, records on 19 August 1623 that he relicensed a later copy of The Winter's Tale without re-reading it, admitting that he took the word of John Heminges that 'there was nothing profane added or reformed, thogh

the allowed booke was missing, ${ }^{x x i}$ It is not clear if Heminges presented Herbert with a printed copy of the play taken from the newly published Folio edition, and now being used by the actors as their book, or offered him an old transcript of the lost manuscript book. In any case, the copy used to print The Winter's Tale shows the characteristics of Ralph Crane, including regularisation in act-scene notations, heavy punctuation and regularised speech-prefixes and stage directions. However, at least three passages in the play have been seen by scholars as later revisions: John Dover Wilson contended that the Time-Chorus in Act 4, Scene 1, was a later nonauthorial addition; Stanley Wells suggested that the 'Dance of the Satyrs' in Act 4, Scene 4 was a later authorial addition; ${ }^{x x i i}$ and more controversially, many have claimed that the re-appearance of Hermione at the end of the play was a clumsy authorial addition. Simon Forman's failure to mention Hermione's reappearance at the end of Act 5 when he saw the play in performance in 
1611, as well as numerous references in Act 3, Scenes 2 and 3, Act 4, Scene 2, and Act 5, Scene 2 to her apparent death that Shakespeare let stand, may suggest that the end of the play was not the original or that it was altered for a performance to celebrate the marriage of Princess Elizabeth in 1612-13. ${ }^{\text {xxiii }}$ However, the awkwardness of the play's conclusion may simply signal Shakespeare trying to suit the fantastical style now demanded by audiences accustomed to seeing masques and other stylised private entertainments. The Folio text, printed at the end of the Comedies, may have been a late insertion there. ${ }^{\text {xxiv }}$

The 'allowed book' of The Winter's Tale may have been lost by mid 1623, several months after the Folio had been printed, because Crane used it to make his copy and then misplaced it. But given the rigours of the repertory system, sets of foul papers, fair copies, and most particularly licensed books were subject to damage and loss. Greg probably correctly argues that Crane copied his text of The Winter's Tale from Shakespeare's foul papers, dismissing the idea that the play was copied from assembled actors' parts or scripts. ${ }^{\mathrm{xxx}}$ John Heminges's insistence to Herbert that 'there was nothing profane added or reformed' in 1623 suggests both that the play had not undergone revision after its first licensing by 1611 and that its treatment of Hermione's resurrection had not been considered profane or censorable in the original. Unlike his predecessors in the position of censor, Sir Edmund Tilney and Sir George Buc, Herbert exerted a great deal of control over players, even when in relationships of mutual trust with them. So we should assume that Heminges spoke truthfully to Herbert and that The Winter's Tale was printed in a form very close to its original composition rather than compiled from a text containing three or more awkward sets of revisions. While Shakespeare may have made some revisions before or after court or other performances, we do not need to excuse the supposed 
weaknesses in Shakespeare's late style by claiming that the text was tampered with after its original composition. Instead we need to see here an author willing to reconsider the formulas and conventions that he had outgrown. If he revised the play, he did so because he wanted to, not because he needed to.

\section{The Tempest}

Apparently printed from a theatrical transcript copied by Crane, The Tempest may preserve some evidence of revision, as well as the addition of the masque, in 1613, as part of the celebrations for the wedding of Princess Elizabeth, two years after the play is recorded as being performed at court on 1 November 1611. Or at least that is what many scholars have claimed, largely because the play has especially full and descriptive stage directions. Frank Kermode dismissed these arguments of later insertions, claiming instead that the play existed from the time of its composition as it came to be printed in the Folio in $1623 .{ }^{\text {xxxvi }}$ In addition, the play's status as the last non-collaborative play of Shakespeare's career may make us want to see him getting it right the first, and last, time. Again, the play shows Crane's characteristics, including heavy punctuation and parentheses, regularisation of act-scene divisions and speech prefixes, and the presentation of a list of character names at the end. As the first play printed in the Folio, at the head of the 'Comedies', Crane's transcript may have served 'as a model for the collection' and copied from Shakespeare's foul papers, evidenced by the lavish stage directions, which Crane may have seen enacted in performances of the plays. ${ }^{\text {xxxii }}$ As Peter Beal notes, the play's songs proved so popular that they were heavily circulated in manuscript form throughout the seventeenth century. ${ }^{\text {xxxiii }}$ David Lindley cogently argues that 'Shakespeare himself must have been involved in rewrites and modifications of his text' but he 'may well 
have been content to accept alteration and adaptation that fitted his texts to the company's needs' xxxix Shakespeare's adherence for the first time to the three unities, ironically towards the end of his career, shows a concern for the play's coherence that is matched by the cleanness of the text. ${ }^{2}$

\section{Henry VIII}

Although more famous since 1613 for burning down the original Globe theatre on 29 June of that year, after a cannon used for stage effects set fire to the thatched roof, than as an outstanding play, Henry VIII or All is True was also a collaboration between Shakespeare and Fletcher. Most likely printed from a scribal transcript, the Folio text of the play has few textual problems. Cyrus Hoy assigned the following scenes to Shakespeare: Act 1, Scenes 1 and 2; Act 2, Scenes 1, 2, 3 and 4; the first half of Act 3, Scene 2; Act 4, Scenes 1 and 2; and Act 5, Scene 1, with the rest of the play written by Fletcher, who may have made minor revisions to portions of Shakespeare's text. ${ }^{\mathrm{xl}}$ As R. A. Foakes succinctly notes, 'the text is a very good one, with act and scene divisions and full, very elaborate stage directions, which are necessary to set out the play's pageantry' ${ }^{x l i}$ Greg called the copy for the Folio a 'carefully prepared manuscript', although there are a few signs of the types of confusions in inconsistent stage directions and speech-prefixes caused by composing authors that have been left intact. ${ }^{\text {xlii }}$ Thus we have further confirmation that company scribes or bookkeepers did not fully correct or amend a text but did a minimal amount of regularisation. Again, the text shows Shakespeare entrusting the full transmission of his text to his colleagues. He may have done so because he was one hundred miles away from London in Stratford. Or he may have assumed that joining a collaborative

\footnotetext{
${ }^{2}$ For a discussion of Shakespeare's later style, which may explain the cleanness of the text of "The Tempest”, see Russ McDonald, 'You speak a language that I understand not': listening to the last plays, in The Cambridge Companion toShakespeare's Last Plays, 91-111.
} 
play was Fletcher's regular role when writing with Beaumont or possibly for other reasons. However, that Shakespeare handed over his text does not mean that he dispensed with it, particularly if he and his company were considering publishing a collected edition of his plays. Clearly, with Henry VIII and The Two Noble Kinsmen, Shakespeare was following a well-established routine in an acting company and in playhouses with which he had had many years of experience. He is not marginalised by the company or even self-marginalised, but the first and lead part of a long and circular transmission process, which he knew at any point could bring the text back to him.

\section{The Two Noble Kinsmen}

Scholars largely agree that Shakespeare wrote this play with John Fletcher, with Shakespeare responsible for Act 1, Scene 2 through Act 2, Scene 1; at least Act 3, Scene 1; the end of Act 5, Scene 1 through Act 5, Scene 3; and Act 5, Scenes 5 and 6; with Fletcher responsible for the rest of the play. ${ }^{\text {xliii }}$ The large share of Fletcher in the play may be one of the reasons that it was not printed in the First Folio, which was designed to show off Shakespeare's canon. The play was first printed in 1634 in Quarto form. William Montgomery argues that the Quarto was set from Shakespeare and Fletcher's foul papers, or a close transcript of them, showing layers of later authorial and non-authorial revision and/or theatrical annotation, first by a bookkeeper in 1613. The text was evidently annotated again for a revival in 1625 or 1626 most likely by Edward Knight, the King's Men's bookkeeper at the time, who inserted the names of two minor actors: 'Curtis' Greville and 'T. Tucke' (that is, Thomas Tuckfield) in stage directions for Act 4, Scene 2, and Act 5, Scene 3. Eugene Waith posits that the manuscript behind the Quarto was Knight's fair copy of the entire 
play. ${ }^{\text {xliv }}$ As this text shows the same awkwardness in the joins of the collaborators' portions in Henry VIII, Fletcher seems to have incorporated Shakespeare's portions of The Two Noble Kinsmen into his own. Shakespeare's apparent generosity, and modesty, in allowing his more junior colleague to put the two sets of foul papers together may have been ultimately misplaced in terms of the play's style. But he must have had some confidence that Fletcher, and the King's Men, in which Shakespeare was still an investor, could manage the transmission of the play's text in an effective way, especially as Fletcher had just finished a successful and long-term collaboration with Francis Beaumont, who retired in 1613. What seems lacking here is any sense of Shakespeare's attempt to control a text's transmission, probably because he knew that such control was not only futile but incompatible with the author's role. While the poet is of 'imagination' all compact, as Theseus tells us in A Midsummer Night's Dream, it is the audience's and not the poet's imagination that truly transmits a text. ${ }^{\text {xlv }}$

\section{Conclusion}

That only one of Shakespeare's last seven plays appeared in print before his death and before the publication of the First Folio, while nearly half of his earlier plays had been printed from some form of Chamberlain/King's Men copy, offers us some idea of the nature of his authorial control. Before 1608, Shakespeare and his company may have been willing to sacrifice sole access to their repertory plays in order to build a following with the reading public. The company seemed to release the most popular of his plays to printers, allowing one of their resident dramatists to reach not only theatrical but literary audiences. In this way, Shakespeare was able to gauge the extent of his reputation and success through the full transmission of his plays from audience to censor to players to print and to both types of audiences, theatrical and reading. But 
by the end of his career, he and his company seemed to become more proprietary, perhaps not just with other companies who could perform any play once it came out in print. The tightening control of Shakespeare and his company in terms of his plays' transmissions ensured that their only publication was an aural one in performance, rather than in print, perhaps in anticipation of the official and supervised transmission of these texts in a volume of collected works.

The five late plays that were eventually published first in the 1623 First Folio were printed from a variety of copy: foul papers; a mix of foul and authorial fair copy; scribal copy; and theatrical manuscript. Each of these types of copy show the kinds of small and large scale revisions, cuts and alterations and marginal additions typical of Shakespeare throughout his career. Thus the King's Men did not cherish or privilege a particular type of Shakespearean text, despite their boast in the First Folio that Shakespeare's plays were 'scarse' without a blot' ${ }^{\text {xlvi }}$ but transmitted in various ways depending on the text and its circumstances. But the tighter the company's control of the text, the more freedom the audience had in participating in this transmission. If Shakespeare, rather than Prospero only, begs of his audience, 'As you from crimes would pardoned be, / Let your indulgence set me free', ${ }^{\text {xlvii }}$ this indulgence included allowing him to decide on the length and breadth of his participation in the transmission of his texts. That we cannot accurately measure this participation means that he has succeeded brilliantly as an early modern dramatist.

Grace Ioppolo, University of Reading

\section{Notes to Chapter 8}

${ }^{\mathrm{i}}$ See Grace Ioppolo, Dramatists and their Manuscripts in the Age of Shakespeare, Jonson, Middleton and Heywood: Authorship, Authority and the Playhouse (London: Routledge, 2006), pp, 140-41. 
ii Jonson, Volpone (London: Printed for Thomas Thorpe, 1607), sig. A4v.

iii Jonson, Dedication, Sejanus, His Fall (London: G. Eld for Thomas Thorpe, 1605), sig. II2 .

${ }^{\text {iv }}$ The Henslowe-Alleyn papers are available online at www.henslowe-alleyn.org.uk; the standard edition of Henslowe's Diary remains that edited by R. A. Foakes and R. T. Rickert (Cambridge University Press, 1960; rpt 2002).

${ }^{\mathrm{v}}$ Dulwich College ms 1:Article 81. In addition to www.henslowe-alleyn.org.uk, photographic reproductions of all these letters and other Henslowe documents are available without transcriptions in The Henslowe Papers, ed., R. A. Foakes, 2 Vols (London: Scolar Press, 1977); Foakes's page numbers, used in the website also, correspond to the manuscript article, not the page, numbers. Transcriptions of the letters were also made by Edmond Malone in his 1821 edition of the works of Shakespeare, by John Payne Collier in The Allyen Papers (London, 1843), and in Greg's The Henslowe Papers (London: A. H. Bullen, 1907), pp. 70-85; all three have occasional errors.

${ }^{\mathrm{vi}}$ For discussions of the circular transmission of the author, see Ioppolo, Dramatists and their Manuscripts, esp. pp. 9ff.

${ }^{\text {vii }}$ For discussions of the textual transmissions of the dates of composition of these plays, see W. W.

Greg, The Shakespeare First Folio: Its Bibliographical and Textual History (Oxford: Clarendon Press, 1955) and Stanley Wells, Gary Taylor, John Jowett and William Montgomery, William Shakespeare: A Textual Companion (Oxford: Clarendon Press, 1987).

viii On the textual situation of Pericles, see the Introductions to Pericles, ed. F. D. Hoeniger (London: Methuen \& Co Ltd, 1963), pp. xxiii and following; Pericles, ed. Doreen DelVecchio and Antony Hammond (Cambridge University Press, 1998), pp.198ff; Pericles, ed. Suzanne Gossett (London: Arden Shakespeare, 2004), pp. 27ff.

${ }^{\text {ix }}$ On the theory of 'bad' Quartos, see A. W. Pollard, Shakespeare's Fight with the Pirates and the Problems of the Transmission of his Text (Cambridge University Press, 1915) and Peter W. M. Blayney's masterful rebuttal of Pollard's theories that 'bad' texts were 'pirated' by printers in The Bookshops in St Paul's Churchyard (London: The Bibliographical Society, 1990). x Philip Edwards, 'An Approach to the Problem of Pericles', Shakespeare Survey, 5 (1952), 25-49, 26, 34-35.

${ }^{\mathrm{xi}}$ DelVecchio and Hammond, Textual Analysis, p. 208.

${ }^{\text {xii }}$ See Hoeniger, Introduction, p. liii; Taylor, William Shakespeare: A Textual Companion, pp. 556-60. 
xiii John Jowett's argument in Wiliam Shakespeare: A Textual Companion, pp. 593-4, that the Folio text was printed from a transcript of the company's promptbook is not supported by any of the play's other modern editors.

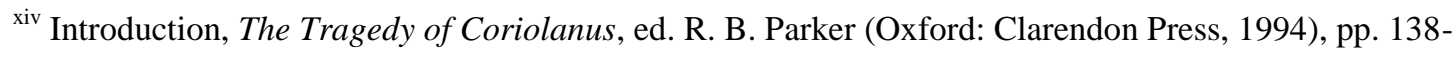
9.

${ }^{\text {xv }}$ Introduction, Coriolanus, ed. Philip Brockbank (London: Methuen \& Co Ltd, 1976), p. 5.

${ }^{\mathrm{xvi}}$ See Ioppolo, Dramatists and their Manuscripts, pp. 102-9.

${ }^{\text {xvii }}$ Shakespeare, Coriolanus in Mr William Shakespeares Comedies, Histories \& Tragedies (London: Isaac Jaggard and Ed. Blount, 1623), sigs. aa2v, aa3v, aa5v.

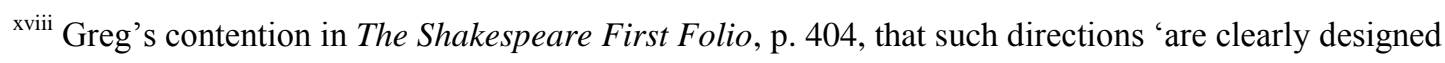
for the producer' assumes, incorrectly, that Shakespeare had no further involvement with company actors on a play once he had submitted the text to them. This type of argument ignores Shakespeare's continuing financial involvement with them.

${ }^{\text {xix }}$ Parker, Introduction, p. 137.

${ }^{\mathrm{xx}}$ See Brockbank's and Parker's Introductions.

${ }^{\text {xxi }}$ Parker, Introduction, pp. 141-42.

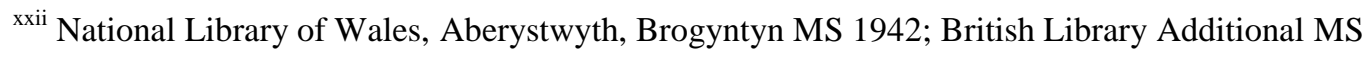
18653; Bodleian Library Malone ms 12 and 25; and Folger MS V.a. 231 and 342. On Crane’s career, see T. H. Howard-Hill, ‘Crane’s 1619 “Promptbook” of Barnavelt and Theatrical Processes', Modern Philology, 86 (1988-9), 146-70.

${ }^{\text {xxiii }}$ See Margaret McLaren Cook and F. P. Wilson's Introduction to their Malone Society Reprints edition of Demetrius and Enanthe (Oxford University Press, 1951).

${ }^{x x i v}$ See T. H. Howard-Hill, Ralph Crane and Some Shakespeare First Folio Comedies (Charlottesville, VA: University of Virginia Press, 1972).

${ }^{\mathrm{xxv}}$ See Wells's and Taylor's Textual Introductions to these plays in William Shakespeare: A Textual Companion, pp. 601, 604.

${ }^{\text {xxvi }}$ Also see James Hirsh, 'Act Divisions in the Shakespeare First Folio', PBSA, 96 (2002), 219-56.

${ }^{x x v i i}$ See Taylor, William Shakespeare: A Textual Companion, p. 604.

${ }^{x x v i i i}$ Greg, The Shakespeare First Folio, p. 412; Taylor, William Shakespeare: A Textual Companion, p. 604. 
${ }^{\text {xxix }}$ See Greg's discussion of Chambers' points in The Shakespeare First Folio, pp. 413-14.

${ }^{\mathrm{xxx}}$ Nosworthy's Introduction to his edition of Cymbeline (London: Methuen and Co. Ltd, 1955), pp. xii-xiii.

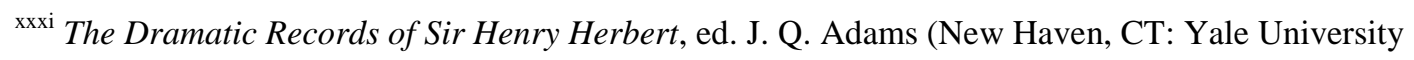
Press, 1917), p. 25; N. W. Bawcutt, The Control and Censorship of Caroline Drama: The Records of Sir Henry Herbert, Master of the Revels 1623-1673 (Oxford: Clarendon Press, 1996), p. 142.

xxxii Wells, William Shakespeare: A Textual Companion, p. 601.

${ }^{\text {xxxiii }}$ See Greg, The Shakespeare First Folio, p. 417; Introduction, The Winter's Tale, ed. Susan Snyder and Deborah Curren-Aquino (Cambridge University Press), pp. 63ff.

${ }^{\text {xxxiv }}$ See Introduction, The Winter's Tale, ed. J. H. Pafford (London: Methuen \& Co Ltd, 1963), p. xvi.

${ }^{\mathrm{xxxv}}$ Greg, The Shakespeare First Folio, p. 416.

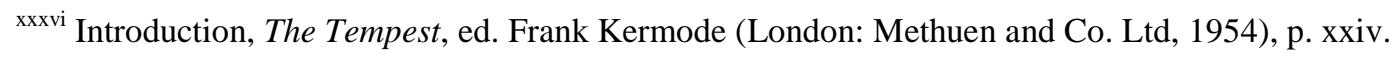

${ }^{x x x v i i}$ Greg, The Shakespeare First Folio, p. 418.

xxxviii See Beal, Index of English Literary Manuscripts 1450-1625, 2 Vols (London: Mansell, 1980), vol. 2, pp. 460-61.

${ }^{\text {xxix }}$ Introduction, The Tempest, ed. David Lindley (Cambridge University Press, 2002), p, 220.

${ }^{\mathrm{xl}}$ Hoy, 'The Shares of Fletcher and his Collaborators in the Beaumont and Fletcher Canon

(VII)', Studies in Bibliography, 15 (1962), 71-90; also see William Montgomery's discussion of the play’s textual history in William Shakespeare: A Textual Companion, pp. 618-19. See also Rory Loughnane's chapter in the present volume (p. 000).

${ }^{x l i}$ Introduction, Henry VIII, ed. R. A. Foakes (London: Methuen \& Co, 1957), p. xv.

xlii Greg, The Shakespeare First Folio, p. 425.

xliii See Cyrus Hoy, 'The Shares of Fletcher and his Collaborators in the Beaumont and Fletcher Canon (I-VII)', Studies in Bibliography, 8, 9, 11, 12, 13, 14, 15 (1956-62); William

Montgomery, William Shakespeare: A Textual Companion, p. 625.

${ }^{x l i v}$ See Montgomery, William Shakespeare: A Textual Companion, pp. 626-9; Introduction, The Two Noble Kinsmen, ed. Eugene M. Waith (Oxford: Clarendon Press, 1989), p. 25.

${ }^{x l v}$ Shakespeare, A Midsummer Night's Dream in The Norton Shakespeare, ed. Stephen Greenblatt (New York, NY: Norton \& Company, 1997), 5.1.8. 
xlvi 'To the great Variety of Readers', in Mr William Shakespeares Comedies, Histories \& Tragedies, sig. A3.

${ }^{x l v i i}$ Shakespeare, The Tempest, in The Norton Shakespeare, Epilogue, 19-20. 